\title{
The Significance of Stage Directions in Aristophanes' "Peace"
}

\author{
Shokhan Rasool Ahmed \\ University of Sulaimani - English Department - College of Languages \\ e-mail: shokhan.ahmed@univsul.edu.iq
}

\section{Abstract:}

This study is principally concerned with the staging of Aristophanes' Peace. John Dee (1527-1609) was the first person to design a clever stage-effect for Greek drama, Aristophanes' Peace, and made a giant beetle that could move from the air down to the stage. The nature and status of stage directions in this play will be investigated, paying particular attention to the status of stage directions in printed text, and whether these stage directions were originally written by the playwright himself or were revised or supplied by editors, scriveners or members of the theatre companies. The paper will also evaluate how the technology of the Elizabethan playhouse facilitated the appearance of dung-beetle on stage.

There was an immense demand in the Elizabethan era for plays about spectacular tricks. People at that time were delighted in the dexterity of the supernatural mysteriousness of the magician and witches, moreover, there was a popular appetite for spectacles within such a 
play. One of the most widespread themes in legend and Elizabethan stage is the flying of supernatural entities. Dragons and dung-beetles are physically manifested differently on Elizabethan stage compared to Medieval and Jacobean stages. Flying of dragons and beetles had a remarkable fiery effect in theatre to create a new genre of spectacle in presenting princely power and martial values to the audience. The special effect of John Dee's flying scarab for a Cambridge performance of Aristophanes' Peace also prompted 'great wondering and many vain reports spread abroad of the means how that was effected' (Jefferies, 2011). In Aristophanes' Peace, Trygaeus rides on the back of a giant dung beetle to heaven in order to arrange peace for the Greeks. The flight scene offers an element of slapstick comedy to the play and makes a comical history out of the flight of the giant beetle. John Dee's stage directions in Aristophanes' Peace are both elaborate and clear which help the reader imagine how the play was staged (Hall \& Wrigley, 2007). The findings of this study would be beneficial for the researchers, the students of English department and theatre companies.

Key Words: Stage directions, Aristophanes' Peace, giant beetle 


\section{Introduction}

Aristophanes' comedy "Peace," which was performed at the Great Dionysia in 421 BC conveys a plot regarding how a war-fatigued farmer called Trygaeus flies to heaven on the back of a dung beetle to search for a lost goddess called Peace (Lada-Richards, 1999). At the end of his journey to heaven, he realizes that the "God of War" has buried Peace in a hole in the ground. Later, a chorus of farmers assists Trygaeus to rescue Peace. The play then ends dramatically with ecstatic merriments in honor of marriage and fertility. Aristophanes wrote the play when the Peloponnesian War, which involved the Athenians and the Spartans, was at its peak (White, 1891). Nevertheless, some scholars have tended to overlook the properties of the stage, in spite of their integral role in ensuring that a play is successfully produced (English, 2000). In effect, such tangible objects may expediently blend into the stage to guarantee specific observations. When it comes to contemporary drama, modern plays have abundant stage directions, which actually depict the mandatory stage properties and at the same time direct how the material objects should be used (English, 2000). It is argued in this paper that, when it comes to the ancient stage productions like Aristophanes' comedy "Peace," understanding it depends largely on precisely how one can reconstruct the visual and aural elements of the play from the stage directions. Today, this depends on the extent that literary and archaeological sources may permit (Mann, 2017). Overlooking the role of stage directions in this context corresponds to disregarding the entire dimension pertaining to the performance of such works. This paper examines the significance of the stage directions in Aristophanes' "Peace".

\section{The background stage directions in Aristophanes" "Peace"}


A review of the stage productions of Aristophanes' Peace in some parts of Europe, particularly France, indicates that all through the 20th century, the performance of his comedies was significantly minimal. This seems to be the case when compared to other works by other Greek tragic playwrights. Not fewer than five professional products of Greek tragedy take place in France annually. On the other hand, the production of Aristophanes comedies, including "Peace", occured just about in 60 occasions from 1900 to 2000. Some commentators have tried to explain that this may have happened because "Peace" is not particularly a French generic taste (Loos, 2009). Precisely, the reason could be linked to distinctive French economic and political cultural organizations. These organizations may have influenced directors to perceive the idea that they have been mandated with an educational and political duty of staging their productions (Ancient Literature, 2019). This is what is perceivable from the historical background of Aristophanes" "Peace" productions in the 20th century in some parts of Europe, particularly France. Indeed, there are strong indications that "Peace" was his most frequently staged play in the period 19002000 in France. This is in comparison to other plays like "Ecclesiazusae" and "Lysistrata", which were briefly staged in the period 1960-1970.

Conversely, French directors, particularly in subsidized theatres, have numerously staged "Peace". Despite this, it is not generally regarded as the best play that Aristophanes ever came up with. In fact, one reason why "Peace" has not been positively received by some of the directors is because its second part is notably long. At the same time, the French directors have often criticized the dirty jokes of excrements, such as the dung-beetle (Rosen, 1984). Accordingly, the main reason "Peace" has been staged with a relative frequency is because of political reasons. Apparently, "Peace" is viewed to be highly political in the modern play productions of Aristophanes' comedies (Classical Arts Universe 2019). There are claims that the play has tended to be staged mostly during political crises. In fact, the chronological events that have marked the stage productions of "Peace" have been reflective of military conflicts, where play directors seek to bring about the message of conflict resolution and peace. Among the most prominent 
directors who have staged "Peace" is Charles Dullin in December 1932, which corresponded to a period in which Hitler was officially elevated to the position of the Weimar Republic's chancellor (English, 2000). Another significant production was in 1961 and 1962 by Jean Vilar, which corresponded to the war in Algeria at the time. Marcel Maréchal also staged the play in Lyon in 1969, which also corresponded to the Vietnam War. Maréchal later staged the play in 1991 at the height of the Gulf War.

\section{The historical significance of stage directions}

Traditionally, scholars have expressed the conception that Greek theatres do, as a rule, have a stage. Over time, scholars of Greek drama have experienced the innate complexities that arise from the different conceptions of a stage (Hall \& Wrigley, 2007). Stage directions consist of unique forms of genre in theatre that range from signals for the dramatic texts, actions, and tones, to the materialization of the playwright's voice. In the case of Aristophanes' play "Peace," stage directions are seen to rise above the play and in the process find an additional function in his comical writings (Hall \& Wrigley, 2007).

The absolute iniquitousness of stage productions in Aristophanes play "Peace" embodies those that existed in the other dramatic genres of ancient times. Indeed, it is safer to argue that Aristophanic's stage directions are significantly linked to the visual elements of the Athenian Old Comedy (Poe, 2000). Ancient sources reveal that Aristophanes' creative use of stage directions to describe material objects on the stage contributed significantly to the success of his comedies. Indeed, as Plato is said to have testified in his works Apology, the fate of Socrates was partially shaped by the visual caricature of him in Clouds a production that happened in its modified form 20 years prior to his execution (English, 2000). Adhering to the demands of the poetics of the Greek theatre makes it possible to understand the traditions of the Western theater, which the notions of the textual content and authorship largely defined. For instance, Aristotle (2006) proposed a number of principles to guide the stage directions in the theatre, which later transformed into the rules of drama. In line with Aristotle's "Poetics", a playwright enjoys the privilege of guiding the course of the play. He relies on stage directions to play the role of the primary stage director. 
Hence, the playwright enhances presence and voice, and makes sure that performances do not go astray from his prior intentions. Hence, stage directions control how a play is received, both by the audience and the actors (Classical Arts Universe 2019). The properties of a stage in a play are essential in practically all theatrical performances. In "Peace," they play a fundamental role in animating the dramatic actions, as they articulate the structure of the plot. To ensure this, they highlight the themes in a play or shape characterization in a play (English, 2000). Aristophanes integrated physical objects into his plays. He extensively used luxury items. He used stage properties that were specially designed for a particular stage, such as the dung beetle. The abundant of stage properties in Aristophanes' play in addition to the varieties of scenes that he conceived demonstrate that the strategic application of objects became a fundamental component for attaining successful productions (Hall \& Wrigley, 2007).

The large quantity of objects is clearly evident in "Peace", as Aristophanes describes them in the stage directions. The abundant number of objects seems to have been intended to bring about dynamism in the play. In turn, stage directions in Aristophanes voice informs the reader of what he wishes to inform them regarding the character in the play, and in so doing enables the reader to fully understand the actors in the play at a more personal level. Sequentially, stage directions serve a crucial function of bringing life to the personalities of the characters, by exposing their inner feelings and conceptions (Hubbard, 1991). Part of the objects is the inclusion of a dung beetle. Later, Trygaeus uses the beetle to fly to heaven (1178). Other objects include battle-mash, which War and Hurly-Burly later blend together (236-88). The play also integrates objects to assist in facilitating a choral group choir practice, which Trygaeus uses with the "chorus" to save Peace (289- 728). Fundamentally, Aristophanes uses stage directions to define what the chorus should consist of. He writes, "The chorus enters; it consists of laborers and farmers from various Greek states." The objects needed for a sacrificial celebration are also provided on the stage, which Trygaeus later prepares to pay respect to Peace (937-1126). Other significant objects included on stage include war tools, which Trygaeus changes into tools of peace (1191-1264). Ultimately, parading 
these objects on the stage puts the audience at a position to determine if such visual elements truly correspond to Aristophanes' era and whether they change over time depending on the period of staging. The staging of Peace using such objects also makes Aristophanes to seem to have ceased from using objects as the groundwork for major dramatic action (Rosen, 1984). Because of this, it is possible that Aristophanes may not have wholly abandoned his earlier techniques over time. He depended substantially on describing the physical objects instead physically presenting them on the stage. Similarly, he used physical humor, domestic farce, wordplay, and allowed them to prevail in his stage productions (Bakola et al., 2013).

The shift in stage productions over time also indicates the changing role of stage directions in cutting the cost of staging a play. Clearly, this indicates that in Aristophanes' early comedies, he tended to build his stages using objects that have been carefully selected. However, this approach seems to have changed in his later plays like "Frogs", which did not require a significant amount of comic spectacles, as was the case with "Peace" (English, 2000). Still, Aristophanes is said to have attempted to adopt a new stagecraft approach. A number of scenes demand fewer modest stage objects to save on the cost of stage production. Indeed, in his later staging, emphasis could only be placed on the costumes of the characters (Revermann, 2014). It is at this stage that stage directions proved to be vital in terms of merely describing the objects that he earlier integrated into the scripts. Indeed compared to Peace, Aristophanes decided to make some objects implicit in the play Frog to significantly draw the attention of his audiences. This is evident in the second part of the comedy (Bowie, 1993). In the opening part of the play "Frog", Aristophanes uses stage directions to announce Dionysus' entry into the stage in a Heraclean lionskin. He also wears ladies' sandals and a club that dangles over his saffron gown. He is in the company of his slave Xanthias, who leads a donkey that carries a luggage pole, bedding and food supplies (Halliwell, 2015). Here, Aristophanes has modestly combined costumes and stage properties to trigger humor, as these objects draw attention to parodies. Similarly, the objects at the start of the play are applied in punctuating 
the actors' physical antics, as they influence Xanthias' donkey, and stress the comical depictions of a set of clothes that Dionysus wears to disguise himself. While Aristophanes did also inspire humor in his play "Peace", he uses a greater number of objects than in the "Frog". Indeed, at the closing scenes of "Peace", Trygaeus has transformed a number of items from an array of hoplite into ridiculous objects (1224- 61). The array of military items that are now out of use, such as trumpet, breastplate, and trumpet, are being provided on the stage, which is in contrast to the comparatively modest objects in his play the world of Wealth or the Frog (English, 2000).

\section{The technical significance of stage directions}

On technical grounds, Aristophanes' play indicates that stage directions are significant to illustrate how the actors should move about a stage while performing a play. Stage directions provide explanations on the directions that a character moves about a stage and the facial expressions that a character should assume. For instance, in a conversation between the First Servant and the Second Servant, stage directions indicate that the First Servant should enter through the stable door (Russo,2002). Afterward, the First Servant says, "Come on, bring us a cake for the beetle. Get a move on! Hurry up." The stage directions then demand that the Second Servant should get on his knees to kneed the dung into cakes. Afterward, the Second Servant says, "There you go. Give him that. May it kill the wretched beast! I hope he never swallows anything more delicious than that ball of shit." The Stage Directions then indicate what the First Servant should do, by demanding that the First servant should take the cake into the stable before returning to the stage. 
Technically, Aristophanes' play also indicates that stage directions decide the tone in which the dialogue is being spoken. Indeed, an additional significance of stage directions is their capacity to convey that atmosphere of the setting of a play. Aristophanes can systematically provide a description of the play's setting. In this way, Aristophanes makes it easy for the audience to understand the characters' surroundings, which in turn allows them to fully understand the play by visualizing it. Accordingly, a reader considers the stage directions as aiding their imagination, by playing a fundamental role in suggesting sensory perceptions (Russo, 2002). For instance, it is possible that certain readers may have a preference for a story that is open-ended or unclear regarding certain themes. In such situations, stage directions permit them the freedom to create images in their minds. On the other hand, other readers may prefer having all the details of the play's setting spelled out. In such an instance, a playwright makes use of "didascaliae" for purposes of controlling how a play is acted out. He or she depends on stage directions, which provide a description of significant dimensions of the setting. Characters are also informed of when they should speak, and the kind of tone they should adopt while addressing other characters. This may include whether an actor should speak in a direct manner to the other characters and whether the character should deliver his or her lines as an aside (English, 2000). While the play "Peace," is meant to be viewed on the stage instead of just read, stage directions could be said to provide an improved understanding of the events that materialize on the stage. This is particularly significant for modern-day actors and audience. For instance, without stage directions, it would be impossible to be aware of when a character should speak in an agitated or angry manner. Often, actors may deduce a gesture from another actor's words. However, readers or the audience may not be aware on condition that he or she is aware of the stage direction.

Stage directions are also significant owing to their capacity to provide particular details and descriptions. They provide a better insight into a storyline and an understanding of what the character feel (Hall \& Wrigley, 2007). Without doubt, the new movements and varieties of drama create a need to 
perform explicit stage directions that enable the audience to subjectively understand abstract thoughts and principles. Indeed, some authors like Russo (2002) have explained how important triggering an emotional state is to a play, as it brings about a sense of human experience or existence. For instance, the stage directions may suggest to actors how to respond to certain stimuli in ways that are typical of human beings. The audience can relate to certain autonomic responses, to perceive the authenticity of a play. Clearly, Aristophanes attempt to illuminate the capacity of bodily response plays a fundamental role in suggesting a sequence of natural bodily responses of actors and characters, which in turn provide a play with greater authenticity (Hall \& Wrigley, 2007). In the play, Aristophanes complements stage directions with dialogue. This is to ensure that facial expressions, actions, and words carry greater meaning than just words alone. For instance, in the dialogue between War and Trygaeus, Aristophanes uses stage directions to portray the tone anger and agitation of the scene, by stating how War "throws some leeks into the mortar," after stating that "Oh! Prasiae! thrice wretched, five times, aye, a thousand times wretched! for thou shalt be destroyed this day." Later, Trygaeus responds to his anger by addressing the crowd that, “This, gentlemen, does not concern us over much; it's only so much the worse for the Laconians." Stage directions are also used to define the tense moment, where "War throws in some cheese" before stating, "Oh, Sicily! you too must perish! Your wretched towns shall be grated like this cheese. Now let us pour some Attic honey into the mortar." In this war, Aristophanes uses stage directions and dialogue to put his audience in comparable physical and emotional moods to those of the characters in the play. Accordingly, rather than just perform anger whenever a standard stage direction states "angrily," Aristophanes stage directions provides the actors with information that facilitates their decision-making regarding the emotions of a certain character, the moment or the entire play ways that are highly nuanced. Yet, this should not imply that stage directions define the historical details of a character lifetime or to provide an explanation of the emotional states of the characters in a concrete way. Instead, they work in collaboration using images and parallel circumstances, in the same way, people demonstrate the same emotional responses in their day by day lives (Nelson 1999). 
An additional significance of stage directions is their capacity to describe the ways in which an act had been conducted. Aristophanes uses stage directions to descriptively inform the audience the manner in which a character performs an action, and in so doing gives the reader a greater accuracy in terms of understanding of what takes place in the play. Owing to Aristophanes' descriptive writing, it is possible for the reader to gain an improved perception of the character's mood, by counting on the manner in which a character reacts to a setting (Araújo \& Pereita, 2016). In the play, stage directions describe the activities that should happen on the stage. In particular, Aristophanes uses stage directions to guide movements of the dung beetle on the stage. This is particularly important when Trygaeus ultimately takes his flight to heaven on the beetle (Russo,2002). In "Peace", Aristophanes uses stage directions describe the precise moment that the beetle should be hoisted up. He also uses stage directons to indicate when Trygaeus should wave his hands to the Athenians, saying, "You, for love of whom I brave these dangers, do ye neither fart nor crap for the space of three days, for, if, while cleaving the air, my steed should scent anything, he would fling me head foremost from the summit of my hopes."

In this way, stage directions also informs the actors of when they should enter the stage and from where, as well as when they should leave the stage and from where. In the play "Peace," stage directors allow the First Slave and the Second Slave to know whether to enter the stage from the right or left, or whether he should enter from the direction that has certain unique configurations (Hall \& Wrigley, 2007). Ultimately, the stage directions have enabled Aristophanes to control human traffic in the stage, and in the process making sure that the characters in the play are saved the disorder of running into each other haphazardly on the stage (Russo,2002). For instance, Aristophanes uses stage productions to describe how the stage should be set. In the first part, Aristophanes introduces two of Trygaeus' slaves. However, before that, he states, "Across the back of the flat open front of the stage, the Orchestra, are four structures: the farmhouse belonging to Trygaeus, a stable beside or in front of it, a cave whose opening is blocked in with rocks, and the palace of Zeus. Two of Trygaeus' slaves are in front of the stable. One is on his knees 
before a shallow tub preparing balls of dung taken from a pile in the yard, and the other is carrying these balls of dung into the stable" (Aristophanes 1912).

Stage directions are significant in the process of staging a play, as they enable the characters to understand what needs to be done with varied stage properties, such as how they should carry their swords. The characters are also informed of the gestures that they should assume, including when they should wave at each other or assume a particular expression or posture. In the dialogue between Trygaeus and the Second Servant, regarding who should be used as a conspirator who sold "Greece to the Medes," and why the "Second Servant" is reluctant to let his boss to go, the stage directions decide when Trygaeus should enter the stage. Here, the stage directions describe the tone that the second servant should use. They require the Second Servant to vociferously exclaim, "Alas! alas! dear little girls, your father is deserting you secretly to go to heaven. Ah! poor orphans, entreat him, beseech him" (Aristophanes 1912). The Second Servant's voice is loud enough that Trygaeus's little daughters in the background can here. In response, the stage directions later describe how Trygaeus's little daughters should enter the stage. It is significant to understand Aristophanes' stage directions using a wider outlook, as instructions intended to guide activities on the stage. The instructions emerge in both the critical text and dramatic text to determine theatricality in a play. They function as authorial instructions intended to ensure that the production of a play is consistent with the original intentions of the author. They also function as an indication of an authorial performance, which emerges during a certain dialogue between the characters (Compton-EngleG., 1999).

This may further imply that in the production of the play "Peace," the relationship between Aristophanes and the play's directors would be conceived from the stage directions of his play, as well as in his critical texts. In the same way, as the dung beetle would be visible on the stages, dung beetles are also described in the stage directions as well as in Aristophanes' subtle authorial performance. In Aristophanes" "Peace", Trygaeus rides on the back of a giant dung beetle to the heaven. In doing so, he 
hopes to arrange peace on behalf of the Greeks. The flight scene offers an element of slapstick comedy to the play and makes a comical history out of the flight of the giant beetle. John Dee's stage directions in Aristophanes" "Peace" are very elaborate and clear which help the reader imagine how the play was staged (Hall \& Wrigley, 2007). In the production of the play "Peace", Aristophanes seems to have decided to use the dung beetle instead of a more intense creature as he intended to inject a sense of humor in the play. Yet, he supports his thoughts by referring to Aesop who injects that the beetle "is the only living thing with wings that ever reached the Gods." The playwright's intellectual capacity, as indicated after Trygaeus meets his daughter and refers to Euripides. Trygaeus's daughter asks him to be to avoid being like tragic heroes like Euripides. It is such conversations that demonstrate that Aristophanes" "Peace" is not primarily concerned with absurd comic components. Rather, it is also a clever conversation that involves great minds whenever it is necessary.

On the other hand, the conception of stage directions when viewed as an archival record of the performance of comic musings of a playwright like Aristophanes' Peace may have contrary effects. They may lead to the conception that long stage directions may actually indicate the fact that a playwright is trying so much to control the body and craft of the actor. Indeed, some authors like Hall and Wrigley (2007) have suggested that actors should overlook such lengthy descriptions and instead allow their sense of character to be their guide. In their view, an experienced actor should be able to read the play and mechanically interpret the most relevant human actions without going through the lengthy descriptions. For instance, the stage directions describe how some objects, in this case, the beetle, should look like, stating, "The Machine brings in Trygaeus astride an enormous figure of a dung beetle with wings spread." Thereafter, Trygaeus states, "Gently, gently, go easy, beetle; don't start off so proudly, or trust at first too greatly to your powers; wait till you have sweated, till the beating of your wings shall make your limb joints supple. Above all things, don't let off some foul smell. I adjure you; else I would rather have you stay right in the stable." 


\section{Conclusion:}

A review of ancient stage productions of Aristophanes' comedy "Peace" demonstrates that gaining a deeper insight into ancient Greek plays is contingent on precisely reconstructing the visual and aural elements of the play using the stage directions. This also means that disregarding the role of stage directions in Peace means ignoring the whole dimension of its successful performance. Modern directors have numerously staged the play Peace because of its political undertones. It is perhaps the most highly political in the modern play productions of Aristophanes' comedies. In the play, the description of a large number of objects seems to have been intended to bring about dynamism. For this reason, stage directions serve a crucial function of bringing life to the personalities of the characters, by exposing their inner feelings and conceptions. Clearly, this indicates that in his early comedies, Aristophanes tended to build his stages using objects that have been carefully selected. However, this approach seems to have changed in his later plays like "Frogs", which did not require a significant amount of comic spectacles, as was the case with "Peace". In the later plays, Aristophanes used stage directions to merely describe the objects and cut on the cost of staging the plays. Aristophanes' play also indicates that stage directions are significant as they illustrate how the actors should move about the stage while performing a play. They also illustrate how the actors should move about the stage while performing a play. Additionally, they decide the tone in which the dialogue is being spoken. 


\section{Reference List}

Ancient Literature. 2019. Peace - Aristophanes - Ancient Greece - Classical Literature. [Online] Available at: https://www.ancient-literature.com/greece_aristophanes_peace.html (Accessed 11 July 2018)

Araújo, V. \& Pereita, A., 2016. Stage Directions Beyond Theater: Eugène Ionesco's exercise in theatricality. Rev. Bras. Estud. Presença, Porto Alegre, 6(2), pp. 331-351

Aristophanes 1912. Peace. Adelaide: The University of Adelaide.

Bakola, E., Prauscello, L. \& Tel, M., 2013. Greek Comedy and the Discourse of Genres. Cambridge: Cambridge University Press.

Bowie, A., 1993, Aristophanes. Myth Ritual and Comedy. Cambridge: Cambridge University Press.

Classical Arts Universe 2019. Aristophanes - Peace - Summary and Analysis - Greek Comedy. [Online] Available at: https://classicalartsuniverse.com/aristophanes-peace-summary-analysis-greekcomedy/ (Accessed 18 November 2018)

Compton-EngleG., 1999, Aristophanes Peace 1265-1304, Food, Poetry, and the Comic Genre. CPh:, 94, pp. 324-329.

English, M., 2000. The Diminishing Role of Stage Properties in Aristophanic Comedy. Helio, 27(2), pp.1.

Hall, E. \& Wrigley, A., 2007. An offprint from Aristophanes in Performance 421 BC-AD 2007. Oxford:

Modern Humanities Research Association and Maney Publishing Legenda.

Halliwell, S., 2015. Aristophanes: Frogs and Other Plays: A new verse translation, with introduction and notes. Oxford: Oxford University Press.

Hubbard, T.K. (1991). The Mask of Comedy: Aristophanes and the Intertextual Parabasis. Ithaca. 
Jefferies, F., (2011). The Gentleman's Magazine. London: Northwestern University.

Lada-Richards, I. (1999). Initiating Dionysus: Ritual and Theatre in Aristophanes' Frogs. Oxford

Loos, P., 2009. Greek Drama. New York: Infobase Publishing.

Mann, K., 2017. The rejected eagle in Aristophanes' Peace. Mnemosyne, 70, pp. 299-307.

Nelson, E. 1999. Stage directions uncovered : the author's voice in modern English drama. Honors Theses Paper, 319

Poe, J.P., 2000. Multiplicity, discontinuity, and visual meaning in Aristophanic comedy.' RhM 143, 25695.

Revermann, M., 2014. The Cambridge Companion to Greek Comedy. Cambridge: Cambridge University Press.

Rosen, R., 1984., The Ionian at Aristophanes Peace. GRBS 46(25), pp.389-396.

Russo, C., 2002. Aristophanes: An Author for the Stage. New York: Routledge.

White, J., 1891. The 'Stage' in Aristophanes. Harvard Studies in Classical Philology, 2(1), pp. 159-205. 